\title{
Nature and Childhood in Wordsworth and Fairuz: A Comparative Study
}

\author{
Dr. Qusai Anwar Al-Thebyan \\ Department of English and Literature, The Hashemite University, Jordan \\ Email: qusai@hu.edu.jo \\ Dr. Halla Ahmad Shureteh
}

Department of English and Literature, The Hashemite University, Jordan

Email: halla@hu.edu.jo

Dr. Bakri Hussein Al-Azzam

Department of English and Literature, The Hashemite University, Jordan

Email: bakri@hu.edu.jo

\section{Doi:10.5901/mjss.2015.v6n3s2p466}

\begin{abstract}
This study aims to illustrate how the Arabic romantic song, "Shadi and I," sung by the distinguished Lebanon's diva, Fairuz, exhibits a thematic parallelism and aesthetic affinities with William Wordsworth's romantic poem "Lucy Gray." Despite the historical and cultural boundaries between the two contexts, the romantic poetic tales of the two children, Lucy and Shadi, display common aesthetic elements related to the conception of nature and the celebration of childhood. Both the poem and the song exhibit conspicuous thematic analogous ideas based on imagination and inspirational communion with nature. In other words, the romanticism of Wordsworth's "Lucy Gray" and the romanticism of Fairuz's "Shadi and I," demonstrate a striking resemblance. The two poems are rich in allegory, vivid in imagery, simple in language, mysterious, and enchanting in their overall effect. Both are also characterized by subjectivity, individualism, love of nature, a sense of loss, amongst other tenets of Romanticism. They deal with the recurring profound themes of despair, child loss and the sinking into the beauty, grace and mysteries of nature.
\end{abstract}

Keywords: William Wordsworth, Fairuz, Nature, Childhood, Romantic, "Lucy Gray", "Shadi and I"

\section{Introduction}

This study attempts to explore the affinity and resemblance of the romanticism of Wordsworth's narrative poem "Lucy Gray" and the romanticism of Fairuz's narrative song "Shadi and I" to one another and to evaluate what is common to both of them.

Wordsworth's lyrical poem "Lucy Gray," or as is sometimes titled "Solitude," was written in 1799 and published in the second edition of Lyrical Ballads (1800), a collection of poems by Wordsworth and Samuel Coleridge, which represents a break with poetic tradition. In his polemical and influential preface added to that edition, William Wordsworth argues that his purpose in writing those poems is to select stories and conditions "of common life" (William Wordsworth, 1800 , p. 235), then to describe such stories in a language that is simple and ordinary, yet "at the same time, to throw over them a certain colouring of imagination" (William Wordsworth, 1800, p. 236). The term 'imagination' is crucial for understanding the allegorical meaning of Wordsworth's poems, and the poet himself was very preoccupied with imagination. Jonathan Wordsworth argues that Wordsworth had the impulse to "turn imagination into something mysterious, beyond human experience" (Jonathan Wordsworth, 1999, p. 487).

"Lucy Gray" is a narrative poem that tells the mystic story of a rural child who disappears into the revered nature. Wordsworth wrote in the footnote of the original poem that he was inspired by a popular story of a child lost in a snowstorm: "It was founded on a circumstance told me (sic) by my Sister, of a little girl who, not far from Halifax in Yorkshire, was bewildered in a snow-storm" (William Wordsworth, pp. 293-294). Much of Wordsworth's poetry is undoubtedly based on his childhood experiences and feelings. Farol states that Wordsworth presents characteristic incidents in his boyhood, such as bathing, skating, card-playing, trapping, and. placid events of an ordinary childhood. In 
addition, he gives examples of experiences of other kinds, fears and pains, as the incident of the stolen boat, illustrating the strange diversity of experience which makes up the boy's life and yet develops into the harmonious calm which is the man's. (Farol, 1933, p. 64)

In "Lucy Gray," Wordsworth attempts to recreate his own feelings following that true incident. However, what had started as a real story turned into a romantic allegorical narrative poem.

Similarly, in the highly emotional and narrative song "Shadi and I," Fairuz yearningly tells a story of a dream or a vision that appeared vividly and plausibly to their minds under the influence of the stunning nature in a way reminiscent of how the Hudson River and the Kaatskill mountains charmed Rip Van Winkle to sleep for twenty years. Rip was intoxicated by the charms of the mountains "seen to the west of the river, swelling up to a noble height," to use Washington Irving's words in his story "Rip Van Winkle." Distinctly enough, "every change of season, every change of weather, indeed, every hour of the day, produces some change in the magical hues"(From Washington Irving's "Rip Van Winkle") which lulled Rip Van Winkle to sleep fast for twenty years, forgetting all nuisances. "Shadi and I" speaks of a similar mystic experience of utmost self-abandonment in nature. The story, recalled in the song, is of a spontaneous and rural child, named Shadi. The name is part of the symbolism created by the poem. 'Shadi' is an Arabic masculine name largely used to mean the one who chants or sings lyric poetry (Ibn Manzuur, 2011, Vol. 7: 41). His story takes place in the vicinity of snow-covered Mount Lebanon and seems to be recalled by the snowy scene setting. The narrator and Shadi were dear childhood playmates. In the song, Fairuz is not only singing Shadi's story, but it is as though she is also expressing her highly personal and deep emotions at his shadowy appearance and disappearance through shifts in her vocal timbre and pitch. At the end of the song, Shadi loses himself entirely to nature, an emphasis on one of the main tenets of the Romantic poetry.

So the poet-narrator, a crucial element of the narrative poem, is common here. As Gregory Dowling points out, in his comment on the form of the narrative poetry, "the poet-narrator has a primary function within the story recounted" (Dowling, 2012, p. 50). In simple words, the poet, disguised in "Lucy Gray" as the narrator, recalls the story of a child. And, in "Shadi and I," the "I" stands for the narrator to intrigue the reader by the same type of fascinating mystery. In both stories, the narrator is unknown and unnamed, yet positioned there in the locale of the events. But unlike the narrator of Wordsworth's poem, who is an older man and whose relation to Lucy is not clear, the narrator of "Shadi and I" is a girl who is about Shadi's age and who gets older and recalls the past events of the poem. Thus, whereas Wordsworth's narrator presents the narrative from an observer's perspective, Fairuz's narrator is personally involved in the events of the story. The narrator used to sing, play and enjoy her time with Shadi in the bygone days of childhood:

\author{
Shadi and I \\ Sang songs together, \\ And over the snow, we tripped along hither and thither. \\ We frolicked and played together. \\ On stones, we carved \\ Little stories, \\ And in the wind we swayed. ("Shadi and I"; our translation)
}

But what is also important is the language used by the narrators of the two poems or rather the poets. Wordsworth is known with his quest for a spontaneous and 'unspoilt' language. He, in fact, insists using a language that is "utterly ordinary and simple and gleaned from the day-to-day lives of the common people" (Choudhury, 2011, p. 13). Wordsworth was more preoccupied with sentiments and he attempted to convey his feelings intimately in a language that is simple rather than rhetorical. Likewise, the language of Fairuz's song is recognized by simplicity and spontaneity. Fairuz's song relies on simple colloquial Lebanese Arabic which sounds like a children plain language. The following analysis of the two poems is intended to reveal more the common romantic aesthetics that make them analogous.

\title{
2. William Wordsworth's "Lucy Gray"
}

In his poems, Wordsworth venerates nature to the point that he, as Burgess writes, was a worshipper of nature. Kuo says that "Wordsworth always worships nature as a religion and praises every beauteous form in it" (Kuo, 2005, p. 193). Kuo adds that Wordsworth "also worships nature as the Supreme Being" (Kuo, 2005, p. 94). Wordsworth describes the setting of his lyrical poems as "Low and rustic" (William Wordsworth, 1800, p. 236)

Because in that condition the essential passions of the heart find a better soil in which they can attain their maturity, are less under restraint, and speak a plainer and more emphatic language; ... the passions of men are incorporated with the 
beautiful and permanent forms of nature. (William Wordsworth, 1800, p. 236)

Lucy Gray is a mystic character. The narrator of the poem says he "Oft ... heard" the sad story of a "solitary child" who with "No mate, no comrade" appeared delicately, furtively and spiritually to him "at break of day" while he was wandering about in nature crossing "the wild." Wordsworth's poetry included the notion of mysticism. Garrod believes that Wordsworth's "mysticism is grounded and rooted actually in the senses" (Garrod, 1963, p. 105). To this effect, Kusi writes

Wordsworth's mystical experience was inspired by the contemplation of Nature which was at the heart of his sensibility. He emphasises on the imagination as agent to capture the physical world in its purest form. His concern was to establish the inextricable link between nature and man in terms of mystical presences in nature that carry with them living souls favourable in conditioning human action and granting freedom. (Kusi, 2010, p. 18)

Moreover, Wordsworth "believes that love, joy, and kindness cannot go without mystic forces in the natural world" (Kangah, n.d., p. 5). Lucy is the spiritual child of nature, begotten of nature, and mystically returns to nature. The slight or momentary dream-like appearance of Lucy could reveal to the narrator that she is like a flower: "The sweetest thing that ever grew." The narrator infers that she is a dweller of nature on an open and "wide moor." Wordsworth humanizes natural objects. Kuo states that "Wordsworth intentionally personifies ... natural objects to create a beautiful and peaceful nook in his mind to evade the sorrow in the human world" (Kuo, 2005, p. 215). Lucy used to have the furtive blithe deer or hares as her only companions in play. They, like Lucy, appear and disappear hurriedly as they are delicate, vulnerable, and furtive. But at lines 12 and 13, the mood of the narrator abruptly changes because she could no more be seen playing and sadly "... the sweet face of Lucy Gray/ Will never more be seen." One could catch sight of her playmates only, the delicate deer and hares playing "upon the green." The tone of the poem subtly changes after her disappearance as the narrator becomes so preoccupied with the unhappy past reminiscences and with the sad story of Lucy's loss through a snowy night. Lucy could no more be seen after she wandered away and perhaps sank into the beautiful mysteries of nature. The sweet little Lucy "gladly" took a lantern to disperse the darkness in her mother's way through "a stormy night," but she wanders away in the snow and never returns. The moon could be seen "yonder" for it was "scarcely afternoon." She was happier than all the roe deer upon the mountain walking up and down the hills, dispersing the snow under her small feet rather spontaneously. The pleasantness of the setting of a mountainous area abundant with roe deer playing furtively here and there was so soon beaten by a snowstorm. The early unexpected snowstorm overwhelms the night and Lucy Gray. Lucy Gray, says the speaker, "wandered up and down" and climbed "many a hill" to reach "the town" but never did. Lucy Gray's parents sorrowfully looks for her "all that night"; they "Went shouting far and wide" for Lucy Gray, "But there was neither sound nor sight" of her. They searched and searched for the small "print of Lucy's feet" in the snow, over the mountainous hills "That overlooked the moor." They searched and wept "all that night" and "At day-break," going "downwards from the steep hill's edge" tracking the "footmarks small" everywhere "through the broken hawthorn hedge,/ And by the long stone-wall;/ And then an open field they crossed" and "Those footmarks, one by one" they tracked until "further there were none." Eventually, the sorrowful parents turned "homeward" because Lucy Gray disappeared into the depth of nature mysteriously as she came furtively through it at the beginning of the poem. Undoubtedly, nature, for Wordsworth, is the source of all pure happiness. In this regard, Kuo says "nature is always endowed with happiness and pleasure in Wordsworth's poems" (Kuo, 2005, p. 211). Havens maintains that "Wordsworth's personification of external nature merges with, or is expressed in a way that suggests, belief in Mother Earth" (Havens, 1941, p. 74). Lucy Gray returns to Mother Nature liberating herself from the cruelty of the previous stormy night. Snow visited the following years with no return of Lucy Gray. So many years passed by, but the blithe "sweet Lucy Gray" remains "a living child" for eternity and may be seen "to this day" over the "the lonesome wild," a perpetual dweller of nature:

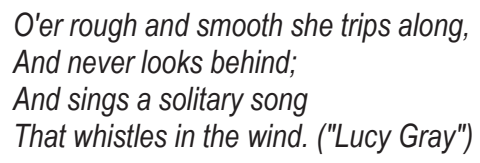

\section{The Romanticism of Fairuz}

Fairuz was born in Beirut in 1934 to a Christian Maronite family; she is

The Arab world superstar .... While a teenager, the tender quality of her voice brought her to the attention of the newly 
founded Lebanese Radio Beirut, which she joined as a chorus singer. There she soon became a leading solo singer, known for her interpretations of classical Arab song. There, too, she met the brothers, Assi and Mansour Rahbani.... Fairuz and the two brothers (Fairuz and Assi married in 1954) worked together .... Assi composed the music; Mansour wrote the words - which in the early part of her career were largely nostalgic and romantic; Fairuz sung, sweeping all before her. The Fairuz/Rahbani team was incredibly prolific and diverse. They reinterpreted classical Arab song, bringing in Western and Eastern European styles (and keys) to the orchestration, combining the piano, guitar, violin and accordion with the nay and Arab percussive instruments. (Broughton 393)

During the 1980s and 1990s, Fairuz was recognized as the Lebanese musical ambassador, singing for peace in her homeland torn by a civil war.

A classified reference list of the musical records of Fairuz shows that "the discography of Fairuz includes a large repertoire of more than 1500 songs" ("Fairuz discography," 2013, Web) of which "Fairuz has sold more than 80 million records world wide" ("Fairuz discography," 2013, Web). Fairuz's voice and songs are widely admired throughout the Arab World. Among many others, Fairuz sang the Romantic poetry of the Lebanese-American poets, Gibran Khalil Gibran and Elia Abu Madi. She is said to have a voice of ethereal beauty. Mahmoud Darwish, the distinguished Arab poet points out that Fairuz' songs are "like our letters to the angels" (as cited in Stone, 2008, p. 150). Shahhada also states "Close your eyes and listen to Fairouz. Her voice is the voice of angles. We cannot see the angles, but sometimes we hear them sing" (as cited in Stone, 2008, p. 150). In many of Fairuz's songs, there is a wide display of high emotional subjectivity and engagement with essentially a wide range of emotional expression of a wide range of romantic themes. In that sense, Fairuz is, like Wordsworth, a conservative Romantic who revered Nature. She revered Lebanon, her homeland, particularly its villages as the repository of happiness and charms. In his article "This Pop Diva Wows 'Em In Arabic," published in The New York Times in 1999, Neil MacFarquhar, no other singer of the Arab world stirs up "the bygone rhythms of village life and the halcyon, prosperous years before wars traumatized their region, sending many into exile" (MacFarquhar, 1999, Web). A lot of what Fairuz sings is about the charms and the bygone charms of Lebanon. Her songs are produced in a rural setting and are more often than not about the village life. Fairuz borrowed the flute from Gibran and sang "singing is the secret of existence and the sound of the flute lives, remains even beyond the end of existence"(originally from a poem by Gibran Kahlil Gibran, titled "Give me the Flute"). Fairuz sang for the heavenly Lebanon and its nature where she used to bathe in its fragrance, dry herself with its light and drink dawn as wine from its divine cups"(from Gibran's poem "Give me the Flute").

Fairuz is known as "Neighbor to the Moon" because in an ethereal voice she sang "We and the moon are neighbors, its house is behind our hills and it rises in front of us to hear our tunes"(from Fairuz's song "We and the Moon Are Neighbors" which was originally composed by the Rahbani brothers). With great commitment and in reference to the Lebanese Civil War and the Israeli invasion of Lebanon, she sang for the homeland promising to return back "from fires and streets destroyed by canons" (from a song by Fairuz, titled "The Bird is Back") despite the terror of battles. "The roaring homeland is destroyed, they say [... ] and the world wept, the world wept boats of tears and emotions of silk" (from Fairuz's "The Bird is Back"). Fairuz sang many nostalgic but "wounded poems [that] reached the end of the world" (from Fairuz's "The Bird is Back"). She sang sad nationalistic songs showing deep sentimental and wistful yearning for the happiness felt in a former time. "Take me to those lovely hills/ Take me to the land that reared us/ Forget me among vineyards and fig trees/ Let me lie upon the soil of our village/ Take me; plant me in the land of Lebanon" (from a song by Fairuz, titled "Take Me to Its Hills"). Fairuz sang lonely songs telling tales of solitude lamenting the endless waiting of a solitary woman "at a crossroad making up fake addresses, and sending news to unknown addressee"(from a song by Fairuz, titled "How Many People There Were," originally composed by the Rahbani brothers). Fairuz sang about every sort of thing. Many of her themes we often take for granted, but once they are brought up in a Fairuz song they put on a charming and exquisite romantic aroma. "Oh grandmother whose voice is ancient, distant and full of warmth [...] I recall the prolonged nights with your winter tales"(a song by Fairuz under the title "Grandmother, Oh My Grandmother"). Her heart yearns deeply for childhood pleasures and wishes her kite which flew away years ago and never came back would return and make her a child again (this is a reference to a song by Fairuz, titled "Fly, O Kite"). She sang for jasmine and all flowers; the baylasan flowers thrown at wedding ceremonies, "they stay alone like the baylasan flowers, alone collecting the leaves of the lifetime; they cover the forest with their shadow like the rain" (from a song by Fairuz, titled "They Alone"). In a very delicate but also reserved style Fairuz sang the best of all Arab poems about love for all times. She sang really soothing lullabies for children and about children, about mothers and for mothers. She sang for seasons, all seasons, spring days and harvest days; all sorts of days around the snow capped Mount Lebanon. "Oh, distant mountain! Behind you there lie our lovers"(from a song by Fairuz, titled "Oh Distant Mountain"). Fairuz sang songs of heart breaking despair, of dreams and visions of a child, a singer, appearing then disappearing in the charming snowcrowned Mount Lebanon. The Harvard expert on Middle Eastern music, points out that Fairuz "made this wonderful mix 
of folkloric art and songs with European instruments and styles that was very appealing .... The whole thing managed to be international, rural and cosmopolitan at the same time" (as cited in Shaplin, 2009, Web).

\section{Fairuz's "Shadi and I"}

Thematically speaking, many of Fairuz's songs tell a romantic story primarily about Lebanon or in Lebanon. "Shadi and I" is a great emblematic song of this category. Like other romantic songs of Fairuz, it seems like a pastoral elegy or a poem of mourning in that it takes much advantage of nature and the rural setting of a mountainous Lebanese village.

At the beginning of this sad song, and under the effect of the divine nature of a mountainous Lebanese village, Shadi appears vividly and credibly to the speaker's mind as her long ago childhood companion in playing and singing. They (Shadi and the speaker) used to sing together as one, ran together over the hills and played till the winds swayed them to and fro in the open where the gorgeous mountains slope to meet the Mediterranean Sea and the bushy valleys. In a very intense and overpowering yearning, Fairuz sings of the past when she was a young girl. Her heart longs for her childhood mate, Shadi, who used to come mysteriously and furtively from the woods to play with her. They used to sing together and play all through snowy days. They used to run and swing through the winds. They used to engrave their little innocent stories on rocks. With a longing heart, Fairuz sang of those dear times. However, Fairuz's beautiful and deep sense of yearning is soon overwhelmed by lament, and the happy reminiscences of Shadi were soon overtaken by grief. Fairuz's romantic song turns into a reflective dirge continuing into the present. From that point on, we hear her sing this dirge for the loss of the well-loved Shadi till the end of the world. Fairuz becomes so engaged with the unhappy past reminiscences and tells the sad story of Shadi's disappearance as children do. Her childlike narrative goes on till the end of the song. She now tells a story of sorrow, fire and all other sorts of the terror of war battles (this is, in fact, a major difference between the two works: the context of war present in Fairuz's song but absent in Wordsworth's poem. It is beyond the scope of this paper to talk about differences as we are basically interested in showing the major affinities and similarities between the two works). "Once upon a day," she says, their world "blazed with fire." The pleasantness of the setting of the mountainous village abundant with nature was so soon beaten by sorrow. The sudden unexpected war and fire overwhelms the setting and Shadi. People got so against each other and were entangled and entrapped in fighting. The fire of fighting mounted and drew near to the mountainous hills of their village. It drew nearer and nearer until the edges of the woods were also caught in the fighting. Shadi ran over the mountainous hills covered with snow to watch, "And never looks behind," to use William Wordsworth's words. Shadi, like Lucy, says the speaker, "wandered up and down" and climbed "many a hill" ("Lucy Gray") to see what was going on, but he never returned. She panicked and cried out "Where are you heading to," but Shadi listened not. She called his name again and again as he went down further and further into the valley and heard her no more. She "went shouting far and wide" but "there was neither sound nor sight" ("Lucy Gray") of Shadi and he never returns. Fairuz sang with emotional sincerity "Never saw I Shadi once more," since girlhood. Shadi wandered away and sank into the beautiful mysteries of nature. The following year, snow visited again, but melted with no return of Shadi. Twenty years, twenty snowy winters passed, yet "the sweet face" ("Lucy Gray") of Shadi "will never more be seen" ("Lucy Gray"). Shadi returns to Mother Nature liberating himself form the cruelty of the storming tensions of life. The speaker grew and grew with distress, yet Shadi remained "a living child" ("Lucy Gray") playing in the snow for eternity. The engagement with nature at the beginning and the communion with nature at the end are so powerful. Shadi disappears into the depth of nature mysteriously as he furtively came through it at the beginning of the song. His communion with nature made him "a living child" ("Lucy Gray") without end, whereas his playmate, the girl, remained in the village and grew up twenty years. Nature was Shadi's resort, his refuge all through. Notwithstanding the girl's lamentation, he drank the elixir of nature and remained a child for ever and a day. As to Wordsworth, "man and Nature," to Fairuz are interconnected. "Yet some maintain that to this day" ("Lucy Gray"), Shadi, like Lucy Gray, is "a living child" that can be seen "Upon the lonesome wild" ("Lucy Gray"). Forever "O'er rough and smooth" ("Lucy Gray") Shadi "trips along," a perpetual dweller of Nature. Shadi, whose name is associated with chanting and singing, "sings a solitary song / That whistles in the wind" up "to this day" ("Lucy Gray").

\section{A Blend of the Romanticism of Fairuz and the Romanticism of Wordsworth}

The chosen Wordsworth's lyrical poem "Lucy Gray" and Fairuz's song "Shadi and I" display common characteristics of Romanticism all through. They are brief, yet reflective and insightful. With an astonishingly similar sad tone, they tell analogous sorrowful, elegiac, and nostalgic stories of a mysterious child loss into nature. In the two poems, the narrator begins the poem with describing an aspect of nature, then he observes a change of appearance in the natural landscape that evokes a complete process of memory, thought, and feelings arising from the described scene. In the course of this 
meditation, the poet comes to understand something after facing a tragic loss and consequently an emotional conflict is resolved. The poems end as they begin, in the outdoor scene but through meditation the poets have come to grasp what is beyond their understanding or end in a state other than the beginning of the poems' moods, overcoming their internal conflict. It is here that the aesthetics of Romanticism, common to both poems, are highlighted where romantic poetry emerges as a liberating force helping the poets to express and come to terms with their grief.

Both narratives are immersed in an elaborate use of the Romantic conventions. In the dream-like stories of "Lucy Gray" and "Shadi and I," the speakers are immersed in deep reminiscences and they tell the stories with a deep sense of yearning for the past where the spiritual roots of the stories extend. In both poems, there is a nostalgic look at the past and there is also a clear focus on subjectivity and on the individual inner feelings of the characters as well as on the narrators predominant feelings of despair and solitude. Moreover, both the song and the poem excessively utilise imagination, making those lyrical pieces truly Romantic.

The ability to go back in imagination to the past gives the poet the ability to see the memories and feel the affections that guide his soul. The poet finds solace in the process of remembrance and meditation that makes him realize that although the splendor of the real scene fades, the memory of the experience remains. The two poems have two fundamental values: childhood, as an optimal state of grace, and nature as an element that incites. Strikingly, as Romantics often do in figuring "children in literature because of ideas about the child's closeness to nature" (Metz, n.d., Web). Fairuz's song and Wordsworth's lyrical poem are occupied and peopled primarily with children as the child is the closest to nature and "has not yet rationalized and assimilated the workings of society" (Metz, n.d., Web) and the complications of the modern world. Through children, Wordsworth and Fairuz show the spontaneity of nature.

Wordsworth and Fairuz display all these conventions with absolute sincerity and spontaneity. At the beginning of both pieces, the closeness to nature is a source of pleasure and nourishment for the body and the soul. All scenes in "Lucy Gray" and "Shadi and I" are portrayed as fresh and remarkable natural images. The blithe lighthearted play and self-abandonment in nature of Lucy Gray and of Shadi appear to be in sharp contrast with the constraints of life elsewhere. In the nature poetry of Romantic writers, natural scenes are romanticized and idealized as sites "where the individual could find freedom from social laws" (Greenblatt, 2006, p. 15). The return to nature in "Lucy Gray" and "Shadi and I" and the mystic disappearance of both children into Nature towards the end take place, perhaps, indicating that nature is the ultimate refuge one could always resort to away from the cruelty of the tensions and constraints of the modern world.

\section{Conclusion}

As seen through the parallel presentation of the storyline of these typically romantic pieces, there are radical striking similarities between the language and circumstances in the stories of the child protagonist of Fairuz's "Shadi and I" and the child protagonist of Wordsworth's "Lucy Gray," which makes the blend of Fairuz and Wordsworth quite effortless.

The specifics of the two romantic stories meet persistently and repeatedly from the very outset of the two stories to the very end. The tone is stunningly the same in both pieces: a bright and cheerful scene is overwhelmed by an escalating sense of sadness and despair. Solitude dominates both the setting and the mood of both pieces. "Wordsworth's imagination is typically released, for instance, by the sudden apparition of a single figure, stark and solitary against a natural background" (Greenblatt, 2006, p. 16). At the beginning, both Shadi and Lucy Gray appear as solitary and dreamlike figures against some romanticized natural scenes. They disappear mystically into nature, but reappear towards the end more solitary and more surreal than before, singing songs of solitude for eternity. The sameness of the resolution of the conflict in both stories through the disappearance of the two spontaneous rural children into nature or rather through the blend of man and Nature makes the blend of Fairuz and Wordsworth truly charming and graceful.

\section{"Lucy Gray" or "Solitude"}

1. Oft I had heard of Lucy Gray:

2. And, when I crossed the wild,

3. I chanced to see at break of day

4. The solitary child.

5. No mate, no comrade Lucy knew;

6. She dwelt on a wide moor,

7. --The sweetest thing that ever grew 
8. Beside a human door!

9. You yet may spy the fawn at play,

10. The hare upon the green;

11. But the sweet face of Lucy Gray

12. Will never more be seen.

13. "To-night will be a stormy night--

14. You to the town must go;

15. And take a lantern, Child, to light

16. Your mother through the snow."

17. "That, Father! will I gladly do:

18. 'Tis scarcely afternoon--

19. The minster-clock has just struck two,

20. And yonder is the moon!"

21. At this the Father raised his hook,

22. And snapped a faggot-band;

23. He plied his work;---and Lucy took

24. The lantern in her hand.

25. Not blither is the mountain roe:

26. With many a wanton stroke

27. Her feet disperse the powdery snow,

28. That rises up like smoke.

29. The storm came on before its time:

30. She wandered up and down;

31. And many a hill did Lucy climb:

32. But never reached the town.

33. The wretched parents all that night

34. Went shouting far and wide;

35. But there was neither sound nor sight

36. To serve them for a guide.

37. At day-break on a hill they stood

38. That overlooked the moor;

39. And thence they saw the bridge of wood,

40. A furlong from their door.

41. They wept--and, turning homeward, cried,

42. "In heaven we all shall meet;"

43. --When in the snow the mother spied

44. The print of Lucy's feet.

45. Then downwards from the steep hill's edge

46. They tracked the footmarks small;

47. And through the broken hawthorn hedge,

48. And by the long stone-wall;

49. And then an open field they crossed:

50. The marks were still the same; 
51. They tracked them on, nor ever lost;

52. And to the bridge they came.

53. They followed from the snowy bank

54. Those footmarks, one by one,

55. Into the middle of the plank;

56. And further there were none!

57. --Yet some maintain that to this day

58. She is a living child;

59. That you may see sweet Lucy Gray

60. Upon the lonesome wild.

61. O'er rough and smooth she trips along,

62. And never looks behind;

63. And sings a solitary song

64. That whistles in the wind.

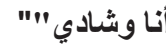

$$
\begin{aligned}
& 1 \\
& 2 \\
& 3 \\
& 4 \\
& 5 \\
& 6 \\
& 7 \\
& 8 \\
& 9 \\
& 10 \text { ـ ركضنا بالهوى لـالت } \\
& \text { 11. كتبنا عالحجار } \\
& \text { 12. 11. قصص صنا عال } \\
& \text { 13. ـ ـولوّحنا الهوى }
\end{aligned}
$$

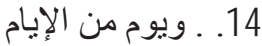

$$
\begin{aligned}
& \text { 15. 15. ولعت الدنى الإيام }
\end{aligned}
$$

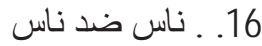

$$
\begin{aligned}
& \text { 17. 17. . علقو ا بها الدنى نانى } \\
& \text { 18. 18. . وصار القتال } \\
& \text { 19. يقرب عالتنال } \\
& \text { 20. . . . و الدنى دنى عالتي } \\
& \text { 21. . . و علقت على أطر اف الو ادي } \\
& \text { 22. . شادي ركض يتفرج } \\
& \text { 23. . خفت 24 . 20 } \\
& \text { 24. ـ ـوصرت اندهله } \\
& \text { 25. . . و وينك رايح با شادي اندي }
\end{aligned}
$$

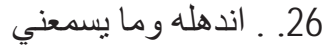

$$
\begin{aligned}
& \text { 27. . . ويبعد يبعد بالو ادي اندي }
\end{aligned}
$$

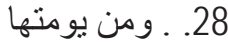

$$
\begin{aligned}
& \text { 29. ـ ما عدت شفتو } \\
& \text { 30. . ضاع شادي }
\end{aligned}
$$




$$
\begin{aligned}
& \text { 31. ـ و التلج اجى } \\
& \text { 32. ـ . وراح التلج داج } \\
& \text { 33. . . عشرين مرة اجى وراح التلج }
\end{aligned}
$$

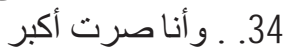

$$
\begin{aligned}
& \text { 35. ـ ـ وشادي بعدو صغير } \\
& \text { 66. 6. عم يلعب عالتلج }
\end{aligned}
$$

\section{"Shadi and l"}

1. Shadi and I

2. Long time ago, when I was still a little girl,

3. There was a child

4. Who used to pop out from the pastoral wild.

5. I played with him, side by side.

6. Shadi was his name.

7. Shadi and I

8. Sang songs together,

9. And over the snow, we tripped along hither and thither.

10. We frolicked and played together.

11. On stones, we carved

12. Little stories,

13. And in the wind we swayed.

14. Once upon a day

15. The world blazed with fire;

16. Each against each,

17. People, in fight, stood against one another.

18. Fighting broke out,

19. It began to get nearer to the mounds,

20. Until the world turned into chaos,

21. Spreading over the sides of the dale.

22. Hurriedly, Shadi went to spy.

23. I, startled,

24. Started to cry:

25. Where are you heading to, Shadi?

26. Many a time I called his name; he heard me nay,

27. Deeper and deeper in the valley he melted away.

28. From that moment to this day

29. Never saw I Shadi once more

30. Shadi was lost.

31. The day's come with snow once again,

32. Yet melted away

33. How oft a blizzard after a blizzard did come then thawed out.

34. Older and older I started to grow,

35. Yet Shadi remained the young boy I once saw,

36. Still frolicking in the snow. (Our translation) 


\section{References}

Broughton, S. et al., eds. (1999). World Music: Africa, Europe and the Middle East: A to Z of the Music, Musicians and Discs. (Vol. 1). London: Rough Guides.

Choudhury, Tahmina A. (2011). Common People in the Poetry of William Blake and William Wordsworth in the Romantic Period. (Thesis). East West University, Bangladesh.

Dowling, Gregory. (2012). The Fascination of What's Difficult: Narrative Poetry in Strict Forms. In Steven P. Schneider (Ed.), The Contemporary Narrative Poem: Critical Crosscurrents (pp. 27-55). lowa: University of lowa Press.

Farol, Honesto F. (1933). The Poetic Doctrines of Wordsworth and Arnold: A Comparative Study of Critical Theories in the Nineteenth Century. (Thesis). Loyola University, Chicago.

Fairuz discography, (2013) [Online] Available: http://en.wikipedia.org/wiki/Fairuz_discography (April 8, 2014).

Garrod, A.W. (1963). Wordsworth. Oxford: The Clarendon Press.

Greenblatt, Stephen. (2006). The Romantic Period 1785-1830. In Stephen Greenblatt (Ed.), The Norton Anthology of English Literature (1-25). (8th ed., vol. 2). New York and London: W. W. Norton \& Company.

Havens, Raymond Dexter. (1941). The Mind of a Poet Vol. 1: A Study of Wordsworth's Thought. Baltimore: The Johns Hopkins Up.

Ibn Manzuur. (2011). Lisaan al- 'Arab. (Vol. 7). Beirut: Dar Sader Publishers.

Kangah, Isaac Ezoulé Miézan, The Healing Power of Nature in William Wordsworth's Poetry. [Online] Available: http://rileci.net/numero1/Article5.pdf (July 24, 2014

Kuo, Gwendolin Huey-jen. (July 2005). A Dialectical Love between Nature and Mind: An Ecofeminist Reading of Wordsworth's Poetry. Dong Hwa Journal of Humanities, 7, 187-222.

Kusi, David T. (2010). Formative Yearnings in Nature: Critical Precepts in the Reading of William Wordsworth and S. T. Coleridge. Bhatter College Journal of Multidisciplinary Studies, 1(1): 9-19.

MacFarquhar, Neil, (May 18, 1999), This Pop Diva Wows 'Em In Arabic. [Online] Available: http://www.nytimes.com/1999/05/18/arts/thispop-diva-wows-em-in-arabic.html (April 8, 2014).

Metz, Stephanie, Romanticism and the Child: Inventing Innocence." [Online] Available: http://web.utk.edu/ gerard/romanticpolitics/ childhood.html (April 8, 2014).

Shaplin, John, (May 26, 2009), Fayrouz by Neil MacFarquhar. [Online] Available: http://johnshaplin.blogspot.com/2009/05/fayrouz-byneil- macfarquhar.html (April 8, 2014).

Stone, Christopher. (2008). Popular Culture and Nationalism in Lebanon: the Fairouz and Rahbani Nation. New York: Routledge.

Wordsworth, Jonathan. (1999). The Romantic Imagination. In Duncan Wu (Ed.), A Companion to Romanticism (pp. 486-494). Oxford: Blackwell Publishers Ltd.

Wordsworth, William. (1991). Wordsworth's Prefaces of 1800 and 1802. In R. L. Brett and A. R. Jones (Eds.), Lyrical Ballads: William Wordsworth and Samuel Taylor Coleridge (pp. 233-258). London: Routledge. 